\title{
ARSENIC AND COPPER UPTAKE BY CABBAGES GROWN ON POLLUTED SOILS
}

\author{
Nguyen Thi Kim Phuong* and Nguyen Thi Dung \\ Institute of Chemical Technology \\ 01 Mac Dinh Chi Str., 1st District, Hochiminh City, Vietnam
}

Received 18 December 2006

\begin{abstract}
Cabbages (Brassica Juncea (L.) Czern) were grown in pot experiments on typical unpolluted and polluted soils with concentration changing from $20.50-50.00 \mathrm{mgAs} / \mathrm{kg}$ and $156.00-413.00$ $\mathrm{mgCu} / \mathrm{kg}$ dry soil. The results demonstrate the elevation of $\mathrm{As}$ and $\mathrm{Cu}$ in soil may lead to increased uptake by these cabbages subsequent entry into human food chain. It was found 11.84 - $32.12 \mathrm{mgAs} / \mathrm{kg}$ and 46.86 - $94.47 \mathrm{mgCu} / \mathrm{kg}$ dry leaves. It has tendency increase uptake and accumulation of $\mathrm{Cu}$ in cabbage tissue with increasing cultivated time, whereas, it was found accumulation of As in cabbages tissue decreased with time prolonging. The quantity of As and $\mathrm{Cu}$ in these cabbages, were significant higher than $0.2 \mathrm{mgAs} / \mathrm{kg}$ and $5.0 \mathrm{mgCu} / \mathrm{kg}$ fresh vegetable, the permissible limit concentration in fresh vegetable, (FAO/WHO, 1993). This indicated that human may $\mathrm{As}$ and $\mathrm{Cu}$ exposure occur through eating these vegetables.
\end{abstract}

\section{INTRODUCTION}

Terrestrial plants are able to accumulate metals to a substantial extent but survive the stress to differing degrees of vitality. The principle processes for transport of metals from soil to plant root are convection (mass flow) and diffusion. Metal ion uptake can be passive (apoplastic) or active (symplastic). Crop species and cultivars differ widely in their ability to absorb, accumulate and tolerate heavy metals, and they show a range of different mechanisms for protecting themselves against metal uptake. Types of metal tolerance mechanism in plants include selective uptake of ions, decreased permeability of membranes immobilization of ions in the roots removal ion from metabolism by storage in fixed or insoluble forms, etc. Plant uptake metal depends on the concentration and speciation of the metal in soil, the movement of the metal from the bulk soil to the root surface, the transport of the metal from root surface into the root by crossing the membrane of epidermal cells and its translocation from root to the leaf. Each of these processes strongly affects whether a potential toxic element reaches the food chain and each process is strongly affected by the chemical speciation of the element [1].

Copper is a required element for plant growth, as its serves an important role in plant structure and function. However, increased concentration of $\mathrm{Cu}$ in soils can lead to toxic effects in plants. Sometimes, plant test is used to recognize incipient $\mathrm{Cu}$ toxicity in soils. For that reason some authors established an upper critical level value for $\mathrm{Cu}$ toxicity in plant tissue.

Arsenic (As) is ubiquitous the environment and is derived from both natural and anthropogenic sources. As is a nonessential element for plants and inorganic As species are generally highly phytotoxic. As (V) acts as a phosphate analog and can disrupt phosphate metabolism, whereas

* Corresponding author e-mail: nguyenthikimp@yahoo.ca 
As (III) reacts with sulfhydryl groups of enzymes and tissue proteins leading to inhibition of cellular function and death [8].

The aim of this study was to quantify the relative availability of As and $\mathrm{Cu}$ from soil to cabbage uptake and accumulation of these metals in different part of cabbage as well as plant age.

\section{MATERIALS AND METHODS}

\subsection{Soil charaterization}

Agricultural soil was collected from an agricultural site located around Ho Chi Minh city. The physical-chemical properties of the soil was measured and listed in table 1.

Table 1: Selected physical-chemical properties of the soil.

\begin{tabular}{ll}
\hline Soil properties & Values \\
\hline Clay $(\%)$ & 13.52 \\
Silt $(\%)$ & 28.48 \\
Sand $(\%)$ & 58.00 \\
pH & 7.47 \\
OM $(\%)$ & 4.0 \\
Total N (\%) & 0.3 \\
Total P $(\%)$ & 0.4 \\
$\mathrm{~K}_{2} \mathrm{O}(\%)$ & 0.4 \\
$\mathrm{Cu}(\mathrm{ppm})$ & 12.36 \\
$\mathrm{As}(\mathrm{ppm})$ & 4.49 \\
\hline
\end{tabular}

\subsection{Experiment setup}

Air-dried soil was amended with salt of arsenic $\left(\mathrm{NaAsO}_{2}\right)$ and copper $\left(\mathrm{CuSO}_{4} .5 \mathrm{H}_{2} \mathrm{O}\right)$ as solution at different concentrations: $20.5,25,35$ and $50 \mathrm{ppmAs}^{3+} ; 156,179,249$ and $413 \mathrm{ppmCu}^{2+} .1 .5$ $\mathrm{kg}$ amended soil was placed in $20 \mathrm{~cm}$ diameter plastic pots $(2 \mathrm{~L})$. Four replicated were prepared per each treatment. After 4 weeks equilibrium, cabbages seeds (Brassica juncea) were sown directly in pots. After germination, excess seedlings were removed to keep 5 plants per pots. Soils were irrigated daily to maintain the moisture content at $80 \%$ of field moisture capacity with fertilized N, P, K (16:16:8) solution rate $100 \mathrm{kgN} /$ ha to approach optimum yield.. Control treatments were used agricultural soil without contaminated As and $\mathrm{Cu}$. Cabbages were grown under average temperature $30^{\circ} \mathrm{C}, 12 \mathrm{~h}$ of light. Metal concentrations in plant were determined at Day 30, 45 and 60 days after sowing. Leaves were separated from roots and all plant parts were washed with tap water to remove adherent soil particles and rinse with distilled water, dried at $60^{\circ} \mathrm{C}$ for $48 \mathrm{hrs}$ and ground in an agate mortar and pestle to pass a $0.85 \mathrm{~mm}$ (20 meshes) sieve.

\subsection{Elemental analysis}

Cabbages analysis for $\mathrm{As}$ and $\mathrm{Cu}$ were accomplished by digesting in microwave (MarsX). The content of As and $\mathrm{Cu}$, were determined by GF-AAS (GBC-Ultra Z) and Flame AAS (GBCAvanta).

\section{RESULTS AND DISCUSSION}

Significant amount these metals of $\mathrm{As}$ and $\mathrm{Cu}$ in soil was not available (table 2 and table 3 ) 
indicating that only small portion of the total may be reached to the cabbages.

Cabbage grows well in tropical area, after sowing 3 days the crops started germinating. At the early stage, cabbage grew very well even in the high As and Cu contaminated soil. After 20 days germinated, visible damage was most obvious in the youngest leaves whereas the primary leaves and the second pair showed invisible and more evident as plant grew to maturity.

Metals content in plant tissue in this study is not a fixed entity, but varies from month to month, day to day even from hour to hour as well as differing between the various parts of plant itself. The rate movement among tissues varies greatly depending on the plant organ, its age and element evolved.

\subsection{Arsenic concentration and distribution in Brassica juncea}

The results of experiment showed that cabbage could grow in soils contaminated from 20.5 to $50 \mathrm{mgAs} / \mathrm{kg}$. Toxic effect of As inhibited uptake and metabolic activity, which leads to suppressed plant growth and slow development. Visible toxic symptoms are stunted and blackened roots, dried leaf margins. Table 2 presented the accumulation of As in cabbage tissue grown on polluted soil at different concentrations

Arsenic considerable as toxic are listed $5-10 \mathrm{mg} / \mathrm{kg}$ dry leaves [6]. The observation data from these experiments are greater than the list, $11.84-32.12 \mathrm{mgAs} / \mathrm{kg}$ dry leaves.

The concentration of As in cabbage tissue grown on polluted soils were much higher in comparison with the control plant, concentration of As in plant increased with increasing As concentration in soil. Significantly decrease arsenic concentrations in roots and leaves of cabbages grown on soils containing $50 \mathrm{mgAs} / \mathrm{kg}$ dry soil (Fig. 1). It might be due to plant genotype that have low uptake at quite high external concentrations of the element. There was no significant different of As concentrations in cabbages grown on control treatments as time increasing but significant decreasing As concentration in roots and leaves of cabbages as time increasing.

Table 2: Total and availability of soil arsenic concentration, accumulation of As in roots and leaves of cabbage (mean values, $n=4$ ).

\begin{tabular}{lllllllll}
\hline & \multicolumn{2}{c}{ As in soil } & \multicolumn{3}{c}{ Roots As } & \multicolumn{3}{c}{ Leaves As } \\
Trtm. & \multicolumn{2}{c}{ mg kg $^{-1}$ dry weight } & \multicolumn{3}{c}{ mg kg $^{-1}$ dry weight } & \multicolumn{3}{c}{ mg kg weight } \\
& Total & Avai. & D 30 & D 45 & D 60 & D 30 & D 45 & D 60 \\
\hline Contr. & 4.41 & 0.37 & 2.42 & 2.55 & 2.29 & 0.91 & 1.23 & 1.26 \\
No. 1 & 20.50 & 2.06 & 26.71 & 21.99 & 20.28 & 14.13 & 13.27 & 11.84 \\
No. 2 & 25.00 & 2.84 & 48.21 & 38.22 & 27.44 & 25.59 & 23.58 & 18.49 \\
No. 3 & 35.00 & 6.84 & 57.22 & 45.81 & 37.28 & 32.12 & 26.65 & 21.77 \\
No. 4 & 50.00 & 9.18 & 42.22 & 36.75 & 28.26 & 16.00 & 14.58 & 12.48 \\
\hline
\end{tabular}

Trtm.: Treatment, Avai.: Availability, D30, D45, D60 Day 30, Day 45, Day 60; Contr.: Control soil.

The highest As concentration was found at Day 30, the lowest concentration was found at Day 60 , perhaps due to the "exclusion strategy and dilution effect" caused by toxic action of As, after 30 days cabbages limited accumulation in roots and limited translocation to the leaves and biomass production during period. Arsenic located in the roots higher than in leaves as expect. 
There were significant correlations between soil As availability and As cabbage tissue $\left(\mathrm{R}^{2}=\right.$ 0.96 - 0.99) (Fig. 2).

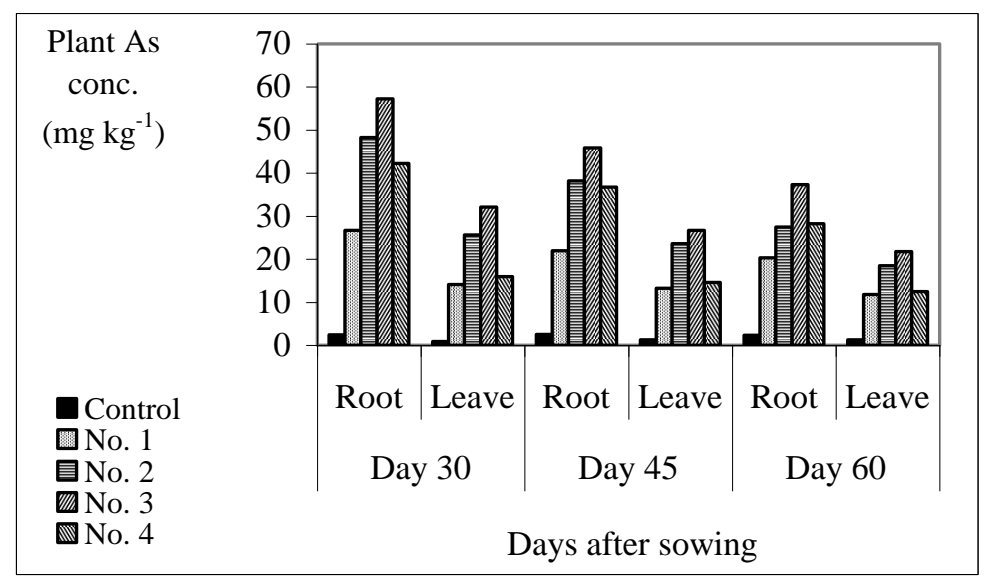

Fig. 1: Distribution of arsenic concentration in root and leave of cabbage grown on control and polluted soil at different harvested time.

Arsenic has been reported to trigger the formation of phytochelatins in plants [5, 9]. Phytochelatins is As-binding peptides with SH-groups, leading to inhibition of cellular function and death. Phytochelatins are considered to be part of detoxifying mechanism of higher plants, immobilized metals are less toxic than free ions $[4,12,9]$.

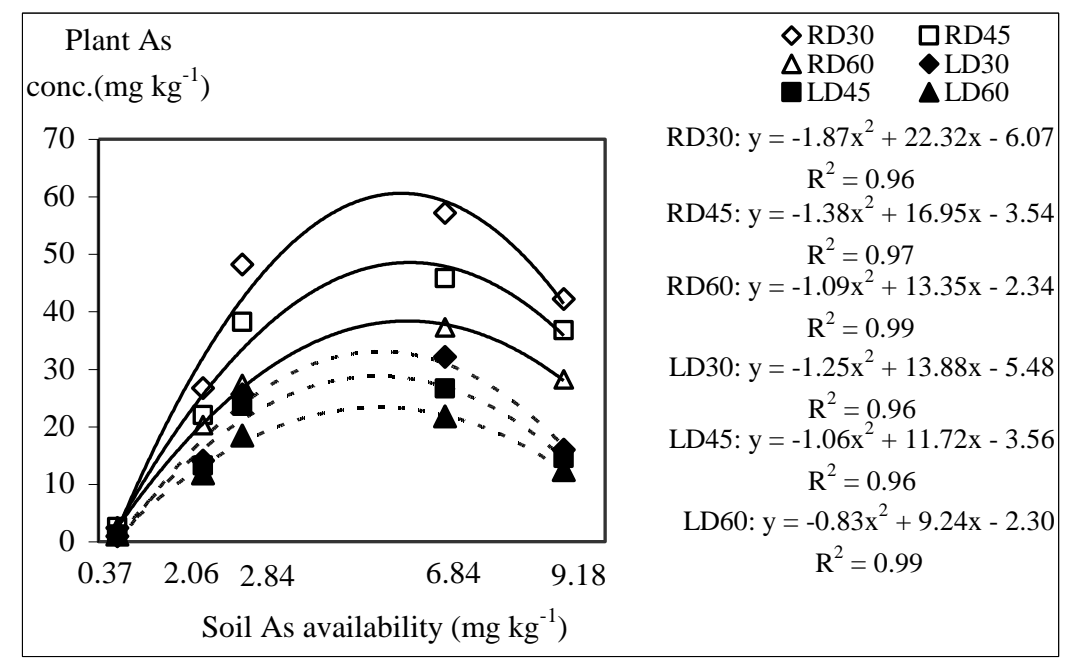

Fig. 2: Relationship of soil As availability and plant As concentration at different harvested time. RD30, 45 and 60: root Day 30, 45 and 60; LD 30, 45 and 60: leave Day 3045 and 60 .

\subsection{Copper concentration and distribution in Brassica juncea}

Both shoot and root growth of cabbage decreased with increasing $\mathrm{Cu}$ concentration in soil. The injury was initiated root system, browning the root increased with increasing $\mathrm{Cu}$ in growth 158 
medium, at higher $\mathrm{Cu}$ treatment $(249.53 \mathrm{mg} / \mathrm{kg}$ dry soil) the root showed dark brown, stunted growth and inhibition of root elongation.

Concentration of $\mathrm{Cu}$ in soil was as low as $156.54 \mathrm{mg} / \mathrm{kg}$, the cabbage growth significantly retarded in comparison with control pot. On pots which had received high doses of copper salt exhibit photo-inhibition and chlorosis in cabbage leaves.

Copper in leaves of cabbages grown on polluted soil was range from 46.86 to $94.47 \mathrm{mg} / \mathrm{kg}$ dry weight (Table 3), significantly higher than healthy plant from 5 to $20 \mathrm{mg} \cdot \mathrm{kg}^{-1}$ dry weight [6]. It was found $\mathrm{Cu}$ accumulation in the roots was higher than in the leaves. The $\mathrm{Cu}$ concentration in plants had a tendency to increase with the age of plant, the highest copper concentration was found at Day 60 (Fig. 3).

Table 3: Total and availability of soil copper concentration, accumulation of $\mathrm{Cu}$ in roots and leaves of cabbage (mean values, $n=4$ ).

\begin{tabular}{lllllllll}
\hline Trtm. & \multicolumn{2}{c}{$\begin{array}{c}\text { Cu in soil } \\
\text { mg kg }^{-1} \text { dry weight }\end{array}$} & \multicolumn{3}{c}{$\begin{array}{c}\text { Roots Cu } \\
\text { mg kg }^{-1} \text { dry weight }\end{array}$} & \multicolumn{3}{c}{$\begin{array}{c}\text { Leaves Cu } \\
\text { mg kg-1 }\end{array}$} \\
\cline { 2 - 9 } & Total & Avai. & D 30 & D 45 & D 60 & D 30 & D 45 & D 60 \\
\hline Contr. & 12.36 & 2.36 & 5.81 & 11.35 & 45.23 & 18.31 & 12.17 & 20.97 \\
No. 1 & 156.48 & 17.88 & 20.63 & 57.10 & 68.69 & 46.86 & 53.97 & 85.07 \\
No. 2 & 179.60 & 26.70 & 23.52 & 75.73 & 92.66 & 49.12 & 61.22 & 92.84 \\
No. 3 & 249.53 & 51.60 & 24.98 & 78.31 & 98.18 & 63.04 & 68.67 & 92.60 \\
No. 4 & 413.75 & 116.76 & 60.68 & 120.21 & 130.87 & 78.59 & 82.89 & 94.47 \\
\hline
\end{tabular}

Trtm.: Treatment, Avai. Availability, D30, D45, D60 Day 30, Day 45, Day 60; Contr.: Control soil.

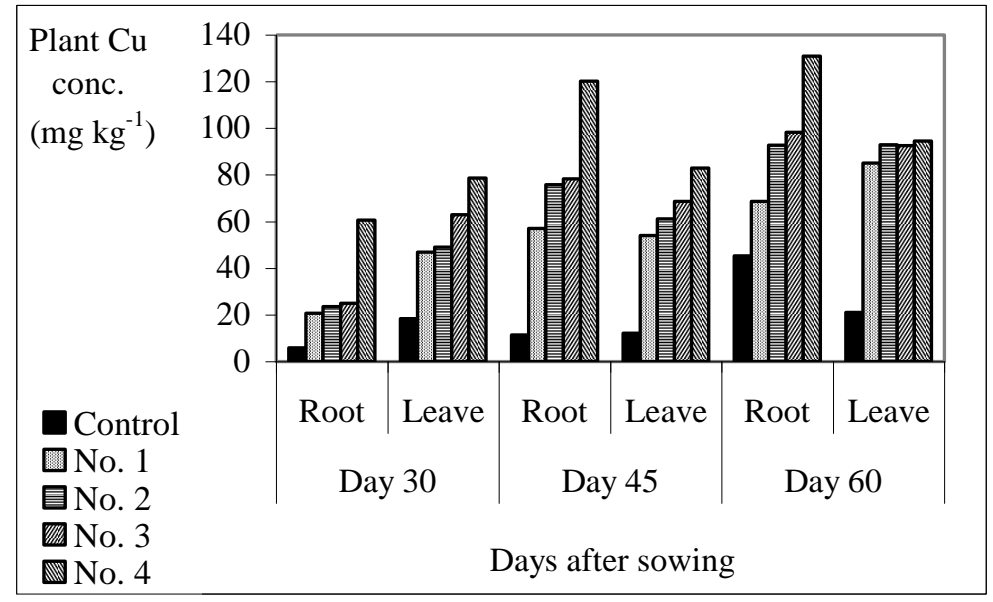

Fig. 3: Distribution of copper concentration in root and leave of cabbage grown on control and polluted soil at different harvested time.

At Day 30, concentration of $\mathrm{Cu}$ in roots was less than in leaves; this indicated that $\mathrm{Cu}$ is mobile elements in cabbage. From 30 to 45 days, the visible damage appeared obvious in the leaves; it 
seemed cabbage limited translocation of $\mathrm{Cu}$ from roots to shoots. Significantly increasing amount of $\mathrm{Cu}$ in the roots at Day 45 whereas not much increasing in case of leaves. However, no such accumulation in roots has been found. There were not much different $\mathrm{Cu}$ concentration between roots and leaves at Day 60 unless in the cabbages grown on pots received highest dose of $\mathrm{Cu}$, this indicated that transfer of $\mathrm{Cu}$ to the top of plant depended upon the function of the roots, when to tolerance mechanisms in the root zone become overload; $\mathrm{Cu}$ is translocated by both the xylem and phloem up to the leaves. Copper contents in roots of cabbages were strongly correlation with soil $\mathrm{Cu}$ availability $\left(\mathrm{R}^{2}=0.91-0.95\right)$, the level of correlations soil copper availability and total copper in leave of cabbages decreased from 0.96 to 0.76. (Fig. 4).

Excess $\mathrm{Cu}$ may replace other metals in metalloproteins or may interact directly with -SH groups of protein [11], $\mathrm{Cu}$ induced free radical formation may also cause protein damage. High concentrations of $\mathrm{Cu}^{2+}$ may catalyze the formation of the hydroxyl radical from $\mathrm{O}_{2}$ and $\mathrm{H}_{2} \mathrm{O}_{2}$. This $\mathrm{Cu}^{2+}$ catalyzed Fenton-type reaction takes places mainly in chloroplasts [10]. The hydroxyl radical may start the peroxidation of unsaturated membrane lipids and chlorophyll and these inhibitory mechanisms might contribute to the observed inhibition of photosynthetic electron transport by excess $\mathrm{Cu}^{2+}[2]$.

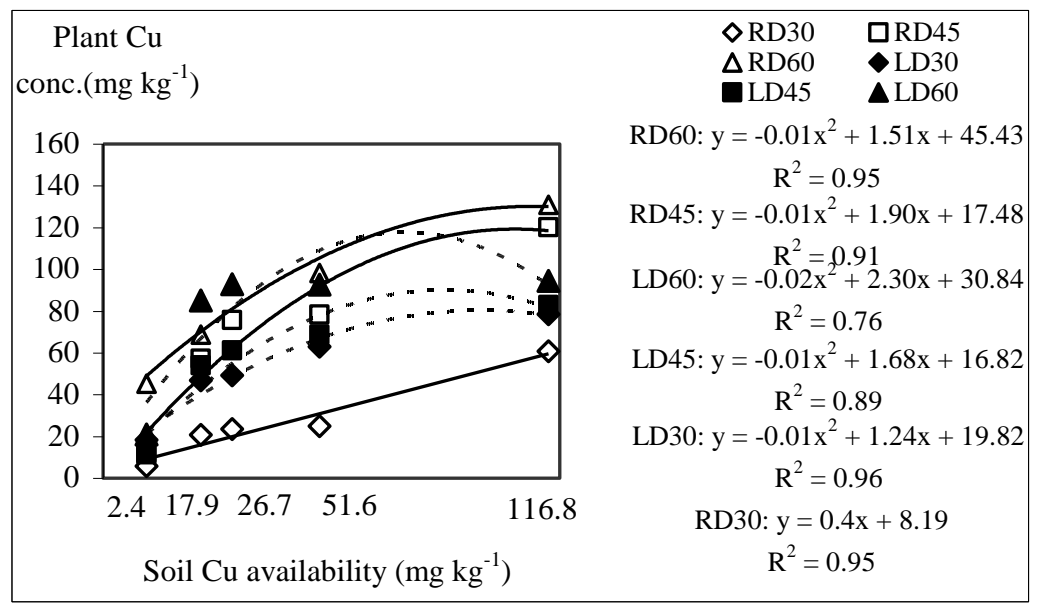

Fig. 4: Relationship of soil $\mathrm{Cu}$ availability and plant $\mathrm{Cu}$ concentration at different harvested time. RD30, 45 and 60: root Day 30, 45 and 60; LD 30, 45 and 60: leave Day 3045 and 60 .

\section{3 $\mathrm{Cu}$ and As concentration in fresh cabbage}

All findings have shown that elevated levels of $\mathrm{As}$ and $\mathrm{Cu}$ in soil may lead to increased uptake by cabbages. So crop uptake and translocation to edible tissue are important process in the analysis of metal movement in food chain. There are public health implications if plant foods accumulate high concentration of metals.

The impact of As and $\mathrm{Cu}$ contaminated in cabbage on human health is more concern and it may correlate with the frequency of these metals contaminated cabbage consumption. The permissible limit concentration in fresh vegetable established by FAO/WHO (1993) is $0.2 \mathrm{mg}$ of As and $5.0 \mathrm{mg}$ of $\mathrm{Cu}$ per $\mathrm{kg}$ fresh vegetable. The quantity of $\mathrm{As}$ and $\mathrm{Cu}$ in these cabbages, were significant higher than those limits, this indicated that human may $\mathrm{As}$ and $\mathrm{Cu}$ exposure occur through eating these cabbages. 
Table 4: As and Cu concentration in edible portion of cabbages.

\begin{tabular}{lllllll}
\hline Trtm & \multicolumn{3}{c}{$\begin{array}{c}\text { As concentration } \\
\text { mg kg-1 fresh weight }\end{array}$} & \multicolumn{3}{c}{$\begin{array}{c}\text { Cu concentration } \\
\text { mg kg }^{-1} \text { fresh weight }\end{array}$} \\
\cline { 2 - 7 } & D 30 & D 45 & D 60 & D 30 & D 45 & D 60 \\
\hline Contr. & 0.09 & 0.12 & 0.13 & 1.83 & 1.22 & 2.10 \\
No. 1 & 1.41 & 1.33 & 1.18 & 4.69 & 5.40 & 8.51 \\
No. 2 & 2.56 & 2.36 & 2.12 & 6.31 & 6.87 & 9.28 \\
No. 3 & 3.21 & 2.67 & 1.85 & 4.91 & 6.12 & 9.26 \\
No. 4 & 1.60 & 1.46 & 1.25 & 7.86 & 8.29 & 9.45 \\
\hline
\end{tabular}

Trtm.: Treatment, D30, D45, D60 Day 30, Day 45, Day 60; Contr.: Control soil.

\section{CONCLUSIONS}

The present of As and $\mathrm{Cu}$ in agricultural soil were significantly increased metal uptake by cabbage and its were well high in comparison with those grown on control pot.

Certain amount of As and $\mathrm{Cu}$ concentration in soil are rising concern about phytotoxicity.

More $\mathrm{Cu}$ was found in the plant with time prolonging; on the contrary, less As in plant tissue was found with increasing cultivated time.

The quantity of As and $\mathrm{Cu}$ in edible tissue of cabbages, were significant higher than the permissible limit concentration in fresh vegetable $0.2 \mathrm{mgAs} / \mathrm{kg}$ and $5.0 \mathrm{mgCu} / \mathrm{kg}$ fresh vegetable (FAO/WHO, 1993). This indicated that human may As and $\mathrm{Cu}$ exposure occur through eating these vegetables.

\section{REFERENCES}

1. Alloway, B.J., ed. (1990), Heavy metals in soils. Glagow: Blackie.

2. Clijster, H. and Van Assche, F. (1985), Inhibition of photosynthesis by heavy metals. Photosynth Res, 7, pp. 31-40.

3. Eija Patsikka, Eva-Mari Aro, and Esa Tyystjarvi (1998), Increase in the quantum yield of photo inhibition contributes to copper toxicity in Vivo. J. Plant Physiol, 117, pp. 619-627.

4. Grill, E., Winnacker, E.-L., and Zenk, M.H. (1985), Phytochelatins: the principal heavy metal complexing peptides of higher plants.J. Science, Vol. 230, pp. 674-676.

5. Grill, E., Winnacker, E.-L., and Zenk, M.H. (1987), Phytochelatins, a class of heavy metal binding peptides from plants, are functional analous to metallothioneins. Proc Natl Acad Sci USA, Vol. 84, pp. 439-443.

6. Kataba Pendias, A. and Pendias, H. (1992), Trace elements in soils and plants. CRC Press, Boca Raton, USA.

7. Li-Men Chen and Ching-Huei Kao (1999), Effect of excess copper on rice leaves: evidence for involvement of lipid peroxidation. J. Bot. Bull Acad. Sin., Vol. 40, pp. 283-287.

8. Meharg, A.A. and Hartley-Whitaker, J. (2002), Arsenic uptake and metabolism in Arsenic resistant \& non-resistant plant species. New Physol, 154, pp. 29-43. 
9. Marcus, E.V. Schmoger, Matjaz Oven, and Erwin Grill (2000), Detoxification of Arsenic by phytochelatins in Plants. Plant Physiology, 122, pp. 793-801.

10. Sandmann, G. and Boger, P. (1980), Copper-mediated lipid peroxidation processes in photosynthetic membranes. Plant Physiol, 66, pp. 797-800

11. Uribe, E.G. and Stark, B. (1982), Inhibition of photosynthetic energy conversion by cupric ion. Evidence for $\mathrm{Cu} 2+$ coupling factor 1 interaction. Plant physiol, 69, pp. 1040-1045.

12. Zenk, M.H. (1996), Heavy metal detoxification in higher plants a review. Gene, Vol. 179, pp. 21-30. 